\title{
Changing Attitudes Toward Checkout Charity
}

\author{
Brenda Massetti ${ }^{1}$, Iris Mohr ${ }^{1} \&$ Mariellen Murphy-Holahan ${ }^{2}$ \\ ${ }^{1}$ St. John's University, New York, New York, United States \\ ${ }^{2}$ St. Thomas Aquinas College, Sparkill, New York, United States \\ Correspondence: Brenda Massetti, Management Department, Tobin College of Business, 101 Astor Place, rm \\ 226, New York, New York, 10003, United States. E-mail: massettb@stjohns.edu
}

Received: August 16, 2019

doi:10.5539/ijms.v11n4p60

\begin{abstract}
Retailers in the U.S. are increasingly asking customers to donate to charity at their sales registers. This practice, known as Checkout Charity, is a form of Cause-Related Marketing (CRM) providing many benefits to retailers (Giebelhausen, Lawrence, Chun, \& Hsu, 2017) and raising billions of dollars for charities (Coleman \& Peasley, 2015). Despite the perceived goodwill of this retail practice, research suggests an imbalance between retailers and consumers, as Checkout Charity offers fewer benefits to customers than traditional CRM (Krishna, 2011; Owens, 2016). Using equity theory's impact on prosocial behavior (Ross \& Kapitan, 2018), this paper explores whether customers perceive an imbalance in the Checkout Charity process. Open-ended survey results show that customers are aware of Checkout Charity's drawbacks and hold mostly negative sentiments toward the practice. Attitudinal survey results show that most customers prefer donating elsewhere and not being asked to donate at checkout. However, some are happy with the process. A regression analysis of factors known to influence charitable giving found that those who donate frequently have a relatively more positive attitude toward Checkout Charity. Research implications and ways retailers might use the practice to build deeper customer relationships are discussed.
\end{abstract}

Keywords: cause-related marketing, checkout charity, business ethics, and social responsibility

\section{Introduction}

In response to the rising demand for corporate social action, U.S. retailers are increasingly asking customers to donate to charity at the sales register (Hessekiel, 2017). Referred to as Checkout Charity, this form of Cause-related Marketing (CRM) allows businesses and charities to collaborate for mutual benefit (Krishna, 2011). Whether by selecting an exact amount or rounding purchase costs to the next dollar; ultimately, customers provide the money while retailers select the charities and transfer the donations. Since its inception, Checkout Charity has raised billions for charities (Coleman \& Peasley, 2015) and increased customer trust and loyalty for many retailers (Trimble \& Holmes, 2013; Giebelhausen et al., 2017). However, it is not without controversy. Concerns exist over the social and financial pressures Checkout Charity places on customers (Krishna, 2011), and questions abound regarding its lack of accountability and transparency (Owens, 2016). Given these many downsides, some suggest customers are better served by refusing to donate at checkout (Siebold, 2014). Doubts have also been raised about Checkout Charity's ability to produce lasting social benefits, suggesting other forms of donation are more equitable and effective (Eikenberry, 2009; White, 2015).

Given the advisory for customers to not donate and the controversy over retailers asking at checkout, two questions arise: why do customers continue to donate; and, is there a way to make Checkout Charity less controversial? To answer these questions, this paper presents the results of two separate surveys. The purpose of this research is to increase understanding of prosocial behavior and guide more sustainable CRM efforts.

\subsection{Checkout Charity in Context}

Historically, businesses have donated to charity for altruistic reasons as well as to garner customer goodwill (Pallotta, 2013). By donating a small percentage of earnings to social causes, businesses enhanced their reputations in the marketplace (Baylin, Cunningham, \& Cushing, 1994). However, dating back as early as the Statue of Liberty restoration campaign by American Express in 1983, businesses began shifting some of their donation responsibility to customers (Krishna, 2011). Specifically, American Express donated money to the Statue of Liberty-Ellis Island Foundation based on how frequently customers performed specific financial 
transactions. Because customers believed they were determining how much American Express ultimately donated, they significantly increased their transactions with the company. American Express increased both revenues and stakeholder goodwill from a humble \$1.7 million contribution (Silva, Wanderley, Sousa-Filho, \& Lucian, 2007) to the estimated \$265 million restoration effort (General Accounting Office, 1986). Given the financial and market success this customer-responsibility shift sparked, other businesses soon began similar efforts and the practice continues to spread globally (Riva, Uddin, \& Rubel, 2019).

Part of CRM's acceptance can be attributed to equity theory, which focuses on creating and sustaining fairness between interacting parties in a social exchange. Equity theory postulates that parties in an exchange assess and compare exchange consequences (i.e., the ratio of benefits to drawbacks) to determine the nature of future exchanges. When an exchange member perceives unfairness, he or she will attempt to reestablish an equitable balance (Huseman, Hatfield, \& Miles, 1987). Through the lens of equity theory, customers respond positively to CRM because they perceive involvement in a company's donation process as more equitable than either not being involved or not having companies donate to charity. CRM also offers businesses a more equitable arrangement as their donation efforts are more directly linked to consumer behavior. Ross and Kapitan (2018) take equity theory's role in CRM further by demonstrating how customers seek a balance in market exchanges. Specifically, they found customers are more likely to display prosocial behavior when they are sensitive to the costs and benefits of market exchanges; and, customers are less likely to display prosocial behavior when they perceive their self-interest has been sidestepped.

\subsubsection{Stakeholder Consequences of Checkout Charity}

Though Checkout Charity is considered a form of CRM it differs in its stakeholder impacts (Trimble \& Holmes, 2013), potentially altering fairness perceptions for retailers, charities, and customers (Giebelhausen et al., 2017). For example, with traditional CRM actual donations from customers are not required, with Checkout Charity they are. Customers might easily perceive this financial shift to be less equitable for them. Table 3 presents a summary of the stakeholder consequences from Checkout Charity found in the academic literature.

Table 1. Stakeholder consequences from Checkout Charity

\begin{tabular}{|c|c|}
\hline Checkout Charity Benefits & Checkout Charity Drawbacks \\
\hline - Retailers: & - Retailers: \\
\hline $\begin{array}{l}\text { - Increased sales and profits (Coleman \& Peasley, } \\
\text { 2015) }\end{array}$ & $\begin{array}{l}\text { - Appearance concerns (Baylin, Cunningham, \& Cushing, } \\
\text { 1994) }\end{array}$ \\
\hline - Increased loyalty and morale (Hartmann, Klink, \& & - Charities: \\
\hline Simons, 2015) & - Loss of message control (Owens, 2016) \\
\hline - Increased public relations and enhanced reputation & - Loss of direct access to donors (Eikenberry, 2009) \\
\hline (Hessekiel, 2017) & - Increased dependency on corporate whim (Silva et al., 2007) \\
\hline - Charities: & - Customers: \\
\hline - Increased financial support (Hessekiel, 2017) & - Loss of money (Siebold, 2014) \\
\hline $\begin{array}{l}\text { - Increased public awareness (Wymer, McDonald, \& } \\
\text { Scaife, 2014) }\end{array}$ & $\begin{array}{l}\text { - Increased social pressure to conform or comply (Krishna, } \\
\text { 2011) }\end{array}$ \\
\hline - Increased managerial advice (Silva et al., 2007) & - Less choice of when, where, and how to heip others \\
\hline - Customers: & (Eikenberry, 2009) \\
\hline • Increased "warm glow" (Giebelhausen et al., 2017) & - Less awareness of where donations go (Owens, 2016) \\
\hline - Donation convenience (Eikenberry, 2009) & - Increased distraction/confusion (Eikenberry, 2009) \\
\hline
\end{tabular}

Given the many benefits retailers receive from Checkout Charity, it is little wonder so many choose this form of CRM. Retailers can expect to increase their sales revenue, employee morale, and customer loyalty (Hartmann, Klink, \& Simons, 2015). Moreover, as customers, employees, and society all want to see companies performing more social action (Coleman \& Peasley, 2015), retailers can also expect to enhance their reputations and receive a public relations boon (Hessekiel, 2017). Also, because they are not donating their own money, their profits are higher. Though there is the potential for retailers to be embarrassed if they select a rogue charity to support (Wymer, McDonald, \& Scaife, 2014), fundamentally, Checkout Charity offers very little downside to retailers.

On the face of it, Checkout Charity's benefits to charities do not appear to differ much from those with traditional CRM. Charities continue to receive corporate support in the form of money, resources, and managerial advice (Silva et al., 2007). They also continue to gain public awareness for their cause and enhance their reputations (Wymer, McDonald, \& Scaife, 2014). However, because individuals overall typically donate 
more money to charity than corporations (Zinsmeister, 2016), charities may ultimately receive more money from Checkout Charity than from traditional CRM. Charities also face similar drawbacks with Checkout Charity. First, they must rely on others to explain the nature and importance of their work, giving them little control over the actual message conveyed. Second, they lack customer contact information, which prevents them from building lasting, direct relationships with those who donate. Third, they must constantly vie for continued campaign support, as retailers can drop one charity for another at any time (Baylin, Cunningham, \& Cushing, 1994).

Customer benefits from Checkout Charity are also similar to those from traditional CRM. It remains convenient, as customers do not have to find a charity and only have to agree to donate the amount requested; and, it produces a positive emotional response for donors (Giebelhausen et al., 2017). However, customer drawbacks from Checkout Charity are more numerous. First, donating customers end up with less money. This means they are less able to spend money in other ways such as paying down debt or saving for their future (Siebold, 2014). Second, Checkout Charity upends traditional customer-retailer relationship expectations. Typically, retailers asking customers for monetary amounts greater than the total sales amount would be considered impolite at best. However, because the request is aimed at charity, customers are supposed to view the retailer as compassionate. Moreover, to keep possession of their extra money, customers must not only refuse an often-pleasant employee but must also risk appearing callous in front of other customers (Owens, 2016). Third, rather than directly helping another, customers can only choose a quick financial fix. Checkout Charity does not allow customers to choose other forms of support such as volunteering their time. Fourth, customers have no way to determine what happens to the money they donate at checkout, since retailers, as private institutions, are not required to show their transactions to the public (Eikenberry, 2009). Fifth, Checkout Charity distracts and potentially confuses customers at the point of purchase. Rather than paying attention to the total amount their purchases are costing; their thoughts are shifted to making a charity donation.

\subsection{Hypotheses}

Applying the logic of equity theory, not only would one expect customers to feel aggrieved by the additional burdens placed on them with Checkout Charity but one would also expect customers to be acting to restore the relational charity-balance with retailers. One obvious way to restore this balance would be to refuse to donate at checkout. However, Checkout Charity donations continue to rise (Fritz, 2019) and customer surveys have shown relatively positive attitudes toward the practice (Good Scout, 2015). A possible reason, customers are not responding as expected might be because Checkout Charity's process interferes with their ability to consider its drawbacks. Similar to impulse buying, where customers fail to consider the downsides for purchasing small items at checkout (Zimmerman, 2012), customers may be agreeing to donate more frequently than they would if they considered all the downsides. To explore this possibility, the authors hypothesize the following regarding customer willingness to donate at checkout:

H1: Customers do not consider Checkout Charity's drawbacks when choosing to donate at checkout.

Given that Checkout Charity represents a prosocial action and customers increasingly want companies to engage in social responsibility (Riva, Uddin, \& Rubel, 2019), customers may be considering the downsides but donate because they value Checkout Charity's benefits more. The amounts requested may seem meager in relation to customers' total-purchase costs or the social costs of refusing to donate may seem greater to them than the financial costs of donating (Konrath \& Handy, 2018). To explore whether customers are making relative comparisons of Checkout Charity's benefits and drawbacks the authors hypothesize the following:

$\mathrm{H} 2$ : Customers perceive the benefits of donating at checkout as more valuable than the drawbacks of donating at checkout.

Yet again, positive customer attitudes and behavior toward Checkout Charity may be the result of factors beyond equity theory's purview. Customers may be reacting to characteristics about themselves or the shopping experience when they decide whether to donate at checkout. Research has identified a variety of factors affecting one's propensity to donate to charity. Generally, women are more likely to donate to charity than men (Mesch, 2016). Older customers are more likely to donate than younger ones; and, those with greater incomes are more likely to donate than those with lesser incomes (Yao, 2015). Also, more educated individuals are more likely to donate to charity as are more generous individuals (Konrath \& Handy, 2018). To explore whether these factors affect donations for Checkout Charity similarly the authors hypothesize the following:

H3a: Female attitudes toward Checkout Charity are more positive than male attitudes.

H3b: The older the customer, the more positive his or her attitude toward Checkout Charity.

H3c: The greater the customer's income, the more positive the attitude toward Checkout Charity. 
H3d: The more educated the customer, the more positive his or her attitude toward Checkout Charity.

H3e: The more generous the customer, the more positive his or her attitude toward Checkout Charity.

\section{Methodology}

To test these hypotheses, the authors gathered and analyzed customer data from two surveys. The first captured customer awareness of the consequences of Checkout Charity. The second gauged customer attitudes toward the practice; and, collected data on key demographic and behavioral factors. An analysis of each hypothesis, including methodology and results follow.

\subsection{Assessment of $\mathrm{HI}$}

Rather than use forced-choice response options which may bias or limit respondents' ability to express their ideas (Singer \& Couper, 2017), the authors used open-ended questions to identify customer perceptions of the consequences of donating at checkout. Specifically, 50 customers responded to the questions listed in Table 2 using Amazon's Mechanical Turk software.

Table 2. Questions to determine reasons for donating or not donating at Checkout

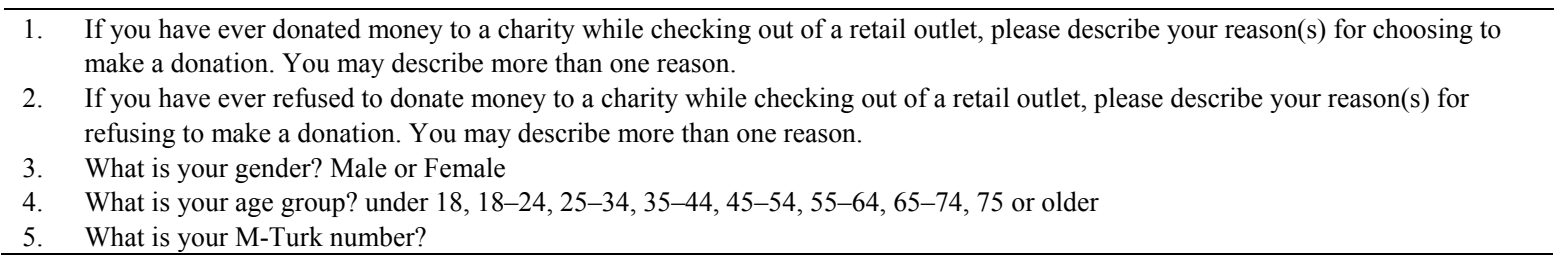

In addition to seeking as many reasons as customers wished to offer regarding their Checkout Charity choices, the authors gathered basic demographic information regarding gender and age. Each customer was paid $\$ 1$ for his/her participation in the survey.

\subsubsection{Results of Open-Ended Survey}

Of the 50 responding customers, seven were in the 18-24 age range, 25 were in the 25-34 age range, and 18 were in the 35-74 age range. Fifty-two percent were male and $48 \%$ were female. Because customers varied in the number of reasons they provided, 43 customers offered 48 reasons for donating. Seven customers offered no reasons for donating, as they claimed they had never donated at checkout. Forty-eight customers gave 64 reasons for refusing to donate. Two offered no reasons for refusing to donate, as they stated they have never refused to donate. Hence, a total of 112 reasons were offered for why people donate or not at checkout.

Based on the similarity of wording and sentiment expressed by the respondents, the authors chose to group the reasons into topical categories. A reason had to be listed by at least three customers (i.e., $5 \%$ of the total number) to be included in a category. Reasons offered by fewer than 3 customers were placed into an "Other" category. Table 3 contains the resulting categories and response frequencies.

Table 3. Reasons for donating or not donating to Charity at Checkout

\begin{tabular}{|c|c|c|c|}
\hline Reason Categories & For Donating & For Not Donating & Totals \\
\hline \multicolumn{4}{|l|}{ Charity Related: } \\
\hline To Support a Specific Charity & 24 & & 24 \\
\hline To Not Support a Specific Charity & & 13 & 13 \\
\hline \multicolumn{4}{|l|}{ Cash Related: } \\
\hline Do Not Have Money to Donate & & 24 & 24 \\
\hline Have Money to Donate & 4 & & 4 \\
\hline \multicolumn{4}{|l|}{ Process Related: } \\
\hline Convenience & 6 & & 6 \\
\hline Do Not Trust Donation Trail & & 6 & 6 \\
\hline Donate Elsewhere & & 5 & 5 \\
\hline Already Given Enough & & 4 & 4 \\
\hline \multicolumn{4}{|l|}{ Emotionally Related: } \\
\hline Negative Sentiments (Guilt, Pressure) & 8 & 8 & 16 \\
\hline Positive Sentiments (Feel Good, Helping) & 3 & & 3 \\
\hline Other & 3 & 4 & 7 \\
\hline Totals & 48 & 63 & 112 \\
\hline
\end{tabular}


Overall, these results show that customers are aware of Checkout Charity's consequences to them, providing no support for H1. The most frequent reason offered for refusing to donate was because customers did not have the money (noted 24 times). Statements like "it's the end of the month and my rent is due" or "I can barely eat" highlight customer awareness of Checkout Charity's costs. Interestingly, because the most frequent reason given for donating was to support a specific charity (also noted 24 times), it appears customers are making conscious decisions. Moreover, because they noted 13 times that they refuse to donate because of the specific charity involved (the third most frequent reason cited in the survey), they are not likely donating on impulse.

Further evidence that customers are aware of Checkout Charity's drawbacks can be found from the process reasons given. Not only were process reasons for refusing to donate more than twice as frequent as those for agreeing to donate but they were also more varied. Customers offered three different process-related reasons for refusing to donate, while they only offered one process-related reason for agreeing to donate (i.e., convenience).

The 19 emotional sentiments customers expressed were overwhelmingly negative, whether they were for agreeing or refusing to donate. With respect to donating, the ratio of negative to positive sentiments was 8 to 3 , meaning that more than twice as many customers expressed negative feelings for donating rather than positive ones. Moreover, only negative feelings were expressed for refusing to donate, and reflected defiance toward Checkout Charity with statements like "I don't like pressure" and "I wasn't letting the guilt affect me".

Overall, from the 112 reasons expressed, we cannot conclude customers are donating because they do not consider Checkout Charity's downsides. However, we also cannot conclude that customers are not considering equity or that they are not comparing consequences when deciding whether to donate.

\subsection{Assessment of $\mathrm{H} 2$}

To explore whether customers donate because they perceive the benefits to be greater than the costs, we developed a 7-point Likert-scale survey to gather various attitudinal aspects of Checkout Charity. The items were based on known customer consequences from published research. Moreover, we included questions to determine their age, education, gender, generosity, and income levels. Amazon's Mechanical Turk was used to gather data from 250 customers, and each respondent was paid $\$ 1.25$ for their effort. To avoid response bias concerns, survey items were randomly presented. For analysis purposes, only 247 surveys were completed.

\subsubsection{Results of Attitudinal Survey}

The survey items, with results, are listed in Table 4. Cronbach's Alpha, which measures the survey's internal reliability, was .927. A Principle Components Analysis identified two attitudinal components within the survey: An Affective variable, composed of items reflecting emotionally based and preferential aspects regarding Checkout Charity $($ Eigenvalue $=7.053$ ); and, a Cognitive variable $($ Eigenvalue $=1.071$ ), encompassing belief-based items. The KMO was .921 and Bartlett's Test of Sphericity was significant at less than .001. Because attitudes are fundamentally composed of both variable types, we continued to assess $\mathrm{H} 2$ using the survey results.

Table 4. Results of attitudinal survey in percentage form

\begin{tabular}{|c|c|c|c|}
\hline Affective Survey Items & Agree & Do Not Agree & Neutral \\
\hline I prefer donating to charity on my own rather than donating at checkout. & $70 \%$ & $15 \%$ & $15 \%$ \\
\hline I prefer NOT to be asked to donate to charity while checking out of a store. & $65 \%$ & $21 \%$ & $14 \%$ \\
\hline I prefer to shop in stores that ask me to donate to charity at checkout. & $9 \%$ & $64 \%$ & $26 \%$ \\
\hline When I am short of money, I do not like being asked to donate to a charity at checkout. & $64 \%$ & $20 \%$ & $16 \%$ \\
\hline $\begin{array}{l}\text { 5. I feel better about the shopping experience when I am asked to donate to charity at } \\
\text { checkout. }\end{array}$ & $14 \%$ & $63 \%$ & $23 \%$ \\
\hline $\begin{array}{l}\text { 6. Even when I am unfamiliar with the charity, I am still comfortable donating at } \\
\text { checkout. }\end{array}$ & $27 \%$ & $62 \%$ & $10 \%$ \\
\hline I wish stores would donate their own money rather than ask for mine to donate. & $61 \%$ & $18 \%$ & $21 \%$ \\
\hline I am tired of stores asking me to donate to charity at checkout. & $55 \%$ & $31 \%$ & $13 \%$ \\
\hline I do not mind retail stores asking me to donate to charity when checking out. & $53 \%$ & $44 \%$ & $2 \%$ \\
\hline 10. Donating to charity at checkout makes me happy. & $37 \%$ & $29 \%$ & $33 \%$ \\
\hline Cognitive Survey Items & Agree & Do Not Agree & Neutral \\
\hline 11. I believe charities benefit greatly from the money collected at checkout. & $53 \%$ & $26 \%$ & $21 \%$ \\
\hline 12. Donating at checkout is easier than donating directly to a charity. & $51 \%$ & $34 \%$ & $14 \%$ \\
\hline 13. I do not believe the money donated to charity at checkout goes where it should. & $34 \%$ & $45 \%$ & $21 \%$ \\
\hline
\end{tabular}

Note. Some item percentage totals do not add to $100 \%$ because of rounding. 
The results show mixed support for H2. Indications that Checkout Charity's benefits are not valued more than it drawbacks can be found in the strong consensus against the practice. In specific, a supermajority (70\%) of customers favor donating to charity on their own, not at checkout; and, $65 \%$ prefer not being asked to donate at checkout. Moreover, $64 \%$ do not like being asked to donate when they are short on cash, and $63 \%$ of customers do not feel better about the shopping experience when asked to donate. Sixty-one percent wish stores would donate their own money, instead of customers' money; and, 55\% are tired of being asked to donate at checkout. Overall, the aversion, resentment and weariness expressed by these percentages supports the notion of perceived unfairness in the process.

Support for $\mathrm{H} 2$ comes from a majority (53\%) of customers also believing that charities benefit greatly from the money donated, and not minding when asked to donate at checkout. Moreover, $51 \%$ find donating at checkout more convenient than donating directly to a charity; and, 37\% feel happy about donating at checkout. So, while many find the practice distasteful, over one-third of those surveyed value the practice of Checkout Charity even with its many disadvantages.

\subsection{Assessment of $\mathrm{H} 3$}

To investigate whether the factors found to influence charity decisions in general also impact Checkout Charity, we performed a stepwise regression analysis to test H3a through $\mathrm{H} 3 \mathrm{e}$. Table 5 summarizes the descriptive statistics of the demographic variables analyzed for the 247 customers who participated in the study. The dependent variable Attitude was calculated by summing responses to the 13 survey items. The total scores ranged from 19 to 84, such that the higher the score, the more positive the attitude toward Checkout Charity.

The independent variables tested were

1) Gender: measured as Female (1) or Male (2);

2) Age: measured in a range from under 18 to over 85 ;

3) Income: measured in a range from less than $\$ 20,000$ to over $\$ 150,000$;

4) Education: measured in a range from less than high school to beyond college; and,

5) Generosity: measured as range of donation frequencies from never to always.

Table 5. Descriptive statistics on demographic data

\begin{tabular}{lll}
\hline Variable & Mean & Standard Deviation \\
\hline Gender & 1.41 & .493 \\
Age & 31.30 & 9.99 \\
Income & 4.97 & 2.79 \\
Education & 4.04 & 1.33 \\
Generosity & 2.00 & .94 \\
Attitude & 56.83 & 13.59 \\
\hline
\end{tabular}

Fifty-one percent of respondents were male and $49 \%$ were female. The average age of customers was 31 years, and most made over $\$ 40,000$ dollars annually. The average education level was college graduate, and most donated sometimes.

\subsubsection{Results of Regression Analysis}

Of all the factors tested, only one, Generosity, was a significant predictor $(p<.001)$ of attitudes toward Checkout Charity $(\mathrm{F}=100.295$, and $\mathrm{R}$-square $=.29)$. Moreover, its Beta coefficient was positive at $\mathrm{p}<.001$ with $\mathrm{t}=10.02$. Consequently, we find partial support H3. In specific, the more frequently a person donates, the more positive his or her attitude toward Checkout Charity. This factor accounts for $29 \%$ of the variance explained and provides a reason for Checkout Charity's success. Those who donate frequently like the practice and continue to donate.

\section{Discussion}

Overall, these findings paint a complex picture of why customers continue to donate in the face of so many drawbacks. Along with an overwhelming cloud of negativity, resentment, and defiance toward the practice lies a ray of trust and expectation for its benefits to charity. Not only do most customers believe that charities benefit greatly from the practice, but many also feel comfortable donating even when they are unfamiliar with a charity. In addition, both surveys provide evidence for perceived wrongness with the process. Many customers resent being asked when they cannot afford to give; and, many more think stores should donate their own money rather 
than ask for customer money. So, while some customers are likely to continue donating regardless of the advisory not to, controversy is also likely to continue if the process remains the same.

While these findings confirm previous research for the most part, the strong degree of negativity noted toward Checkout Charity is new as is the finding that generosity is a more important predictor of positive attitudes toward Checkout Charity than age, gender, education or income. Both have important implications for how retailers might better manage the process. In specific, because those who donate tend to like the practice and those who do not tend to loathe it, retailers could be building better relationships with their customers by categorizing and responding to these two segments differently. Given the massive amounts of data retailers collect about customers, differentiating those who donate from those who do not should be straightforward. Retailers could ask customers signing up for store discount cards what their preferences are regarding Checkout Charity; or, they might track how frequently existing store cards or credit cards are used to donate. In addition, retailers might add a "do not ask again" feature to their donation systems, which could have an added benefit of allowing retailers to track the purchasing behavior of customers previously unlinked to them.

Given the growing competition within retailing, establishing pleasant and convenient relationships with all customers is crucial for sustainable success. So, for "non-donator" customers who prefer not being asked to donate checkout, retailers could stop asking them; choosing to focus instead on having reasonably priced products and brands these "non-donators" wish to buy. By respecting the wishes of "non-donators", retailers resolve the problem of having customers leave their stores feeling wronged while creating an opportunity to learn more about the buying behavior of this customer segment.

For "donator" customers who like and contribute to Checkout Charity, retailers can design programs to increase their foot traffic, store loyalty, reputation, and social goodwill. For example, donor appreciation sales days or coupons could be issued only to customers in this segment. Moreover, retailers can use the data on donation activity to design and build communities of like-minded customers, dedicated to the same social ideals as the retailer. For example, retailers could create charity clubs and in-store charity events where customers can interact, learn how their donations help, and discover opportunities to become more involved. The charities can also participate with a variety of cross-advertising and promotional campaigns with retailers. These perks would not only create deeper relationships with the "donator" customers but could also entice "non-donators" to begin donating so they too benefit from the perks.

\section{Limitations and Future Research}

More research is needed, however, to better understand how Checkout Charity is changing charity, and consumer purchases in general. Even though our research showed that many customers harbor a deep negativity toward Checkout Charity, we cannot be sure how lasting these attitudes are or whether they are generalizable to other forms of CRM. Although our study allowed for open-ended responses from actual customers, field and longitudinal studies where Checkout Charity experiences are observed and customers are interviewed would go a long way in resolving current theoretical inconsistencies. Moreover, determining whether negative attitudes toward Checkout Charity impact traditional CRM would shed light on whether shifting more donation responsibility to customers enhances or harms prosocial behavior long term. We also cannot explain why generosity was the only predictive factor positively correlated with attitudes toward Checkout Charity. Because there is much evidence relating age, gender, income and education to attitudes and behavior toward charity donations (Mesch, 2016; Yao, 2015; Konrath \& Handy, 2018), it is surprising these factors did not correlate with attitudes toward Checkout Charity. Perhaps the perceptual difference between a charity asking for support and a checkout clerk asking alters customers' attitudinal responses to donation behavior.

Moreover, to establish a comprehensive theory regarding Checkout Charity, additional research on how charities and retailers are affected by the practice is needed. For example, research determining whether charities receive more money from Checkout Charity than from traditional CRM would indicate Checkout Charity's ultimate social impact. One would expect supported charities to be having significantly greater social impacts, as their staff can focus more on doing good than on raising funds. There is also the potential for greater social impact from retailers as well. Depending on whether they view Checkout Charity more as a service any good middleman provides or as one social action among many they offer could impact the extent to which society ultimately benefits.

Retailers receive so many benefits from Checkout Charity, it is unlikely the practice will stop regardless of controversy. However, because retailers face ever increasing competition for customers, building on the positivity and overcoming the negativity of Checkout Charity is likely to make the practice fairer and more sustainable for all involved. 


\section{References}

Baylin, G., Cunningham, P., \& Cushing, P. (1994). Cause-related marketing: Ethical practice or exploitive procedure? The Philanthropist, 12(2), 15-33.

Coleman, J. T., \& Peasley, M. C. (2015). Demonstrating a lack of brand/cause effects on point of sale donations. Management \& Marketing. Challenges for the Knowledge Society, 10(3), 226-243. https://doi.org/10.1515/mmcks-2015-0016

Eikenberry, A. (2009). Refusing the market: A democratic discourse for voluntary and nonprofit organizations. Nonprofit and Voluntary Sector Quarterly, 38(4), 582-596. https://doi.org/10.1177/0899764009333686

Fritz, J. (2019, May 23). Checkout charity campaigns succeed because most consumers say yes. The Balance: Small Business. Retrieved from https://www.thebalancesmb.com/checkout-charity-campaign-best-practices-2501825

General Accounting Office. (1986, June). National parks: Restoration of the statue of liberty monument. Washington, DC: Resources, Community, and Economic Development Division. Retrieved from https://www.gao.gov/assets/150/144559.pdf

Giebelhausen, M., Lawrence, B., Chun, H., \& Hsu, L. (2017). The warm glow of restaurant checkout charity. Cornell Hospitality Quarterly, 1-13. https://doi.org/10.1177/1938965517704533

Good Scout. (2015, May). Change at the checkout: The evolution of charitable donations at the register. New York: Good Scout Group. Retrieved https://engageforgood.com/wp-content/uploads/2016/11/ChangeatCheckout_FinalReport.pdf

Hartmann, M., Klink, J., \& Simons, J. (2015). Cause related marketing in the German retail sector: Exploring the role of consumers' trust. Food Policy, 52, 108-114. https://doi.org/10.1016/j.foodpol.2014.06.012

Hessekiel, D. (2017, June 20). Donating at checkout remains high amidst retail slump. Forbes. Retrieved from https://www.forbes.com/sites/davidhessekiel/2017/06/20/charity-checkout-champions/\#6518bf86e136

Huseman, R. C., Hatfield, J. D., \& Miles, E. W. (1987), A new perspective on equity theory: the equity sensitivity construct. Academy of Management Review, 12(2), 222-234. https://doi.org/10.2307/258531

Konrath, S., \& Handy, F. (2018, April). The development and validation of the motives to donate scale. Nonprofit and Voluntary Sector Quarterly, 47(2), 347-375. https://doi.org/10.1177/0899764017744894

Krishna, A. (2011, March). Can supporting a cause decrease donations and happiness? The cause marketing paradox. Journal of Consumer Psychology, 21, 338-345. https://doi.org/10.1016/j.jcps.2011.02.001

Mesch, D. (2016, February 1). The gender gap in charitable giving: Studies show that women are more likely to donate than men, and to donate more. The Wall Street Journal. Retrieved from https://www.wsj.com/articles/the-gender-gap-in-charitable-giving-1454295689

Owens, K. (2016, May 17). 5 Reasons you should run screaming from checkout charity donations. The Huffington Post. Retrieved from http://www.huffingtonpost.com/kim-owens/5-reasons-you-should-run_b_10012906.html

Pallotta, D. (Presenter) (2013, March). The Way We Think About Charity is Dead Wrong. [Video episode] Technology Education and Design Conference, Long Beach, CA. Retrieved from https://www.ted.com/talks/dan_pallotta_the_way_we_think_about_charity_is_dead_wrong

Riva, F., Uddin, M. R., \& Rubel, M. R. B. (2019). Effect of customers' attitude involvement on purchase intention: Moderating effect of cause related marketing campaigns. International Journal of Marketing Studies, 11(20), 75-86. https://doi.org/10.5539/ijms.v11n2p75

Ross, S. M., \& Kapitan, S. (2018). Balancing self/collective interest: Equity theory for prosocial consumption. European Journal of Marketing, 52(3/4), 528-549. https://doi.org/10.1108/EJM-01-2017-0002

Siebold, S. (2014, October 23). Most people shouldn't be giving to charity. Business Insider. Retrieved from https://www.businessinsider.com/most-people-shouldnt-be-giving-to-charity-2014-10

Silva, F., Wanderley, L., Sousa-Filho, J., \& Lucian, R. (2007). Ethics and cause related marketing: Five major ethical conflicts. X Seminários em Administração - X SEMEAD, Universidade de São Paulo. São Paulo. Retrieved from https://www.researchgate.net/publication/299934188_Ethics_and_cause_related_marketing_Five_major_et hical_conflicts 
Singer, E., \& Couper, M. (2017). Some methodological uses of responses to open ended questions and other verbatim comments in quantitative surveys. Methods, Data, Analysis, 11(2), 115-134. Retrieved from https://mda.gesis.org/index.php/mda/article/view/2017.01

Trimble, C., \& Holmes, G. (2013). New thinking on antecedents to successful CRM campaigns: Consumer acceptance of an alliance. Journal of Promotion Management, 19, 352-372. https://doi.org/10.1080/10496491.2013.787381

White, G. (2015, July 23). The inadequacy of corporate social-responsibility programs. The Atlantic. Retrieved from https://www.theatlantic.com/business/archive/2015/07/corporate-social-responsibility/399206/

Wymer, W., McDonald, K., \& Scaife, W. (2014). Effects of corporate support of a charity on public perceptions of the charity. Voluntas: International Society for Third-Sector Research, 25(6), 1388-1416. https://doi.org/10.1007/s11266-013-9397-y

Yao, K. (2015). Who gives? The determinants of charitable giving, volunteering, and their relationship. Wharton Research Scholars. University of Pennsylvania. Retrieved from http://repository.upenn.edu/wharton_research_scholars/126

Zimmerman, I. (2012, July 18). What motivates impulse buying? Psychology Today. Retrieved from https://www.psychologytoday.com/us/blog/sold/201207/what-motivates-impulse-buying

Zinsmeister, K. (2016). The Almanac of American Philanthropy. Philanthropy Roundtable, Washington, DC. ISBN 13:978-0986147456. Retrieved from http://www.philanthropyroundtable.org/almanac/statistics/

\section{Copyrights}

Copyright for this article is retained by the author, with first publication rights granted to the journal.

This is an open-access article distributed under the terms and conditions of the Creative Commons Attribution license (http://creativecommons.org/licenses/by/4.0/). 